\title{
PENGEMBANGAN EVALUASI KETERAMPILAN MENULIS KARYA ILMIAH DENGAN PENDEKATAN SISTEM
}

\author{
${ }^{1)}$ Mimin Sahmini, ${ }^{2)}$ Yeni Rostikawati \\ ${ }^{1)}$ miminsahmini@gmail.com, ${ }^{2)}$ yenirostikawati@yahoo.com \\ ${ }^{1,2)}$ Program Studi Pendidikan Bahasa dan Sastra Indonesia, STKIP Siliwangi
}

\begin{abstract}
ABSTRAK
Karyatulis ilmiah merupakan tulisan yang membahas ilmu pengetahuan disusun secara sistematis dengan menggunakan bahasa yang baik dan benar. Salah satu jenis karya ilmiah adalah makalah. Salah satu pendekatan yang dapat diterapkan dalam menulis makalah adalah pendekatan sistem. langkah awal dari pendekatan sistem adalah perencanaan, pelaksanaan, observasi untuk mengenali kontroversi, refleksi lalu menimbang untuk memecahkan masalah, dan menentukan evaluasi yang tepat dengan permasalahan. Tujuan penelitian ini yaitu untuk mengetahui pengaruh pengembangan evaluasi keterampilan menulis makalah dengan pendekatan sistem.Penelitian ini menggunakan metode penelitian dan pengembangan/research and developments $(\mathrm{R} \& \mathrm{D})$ yaitu penelitian yang menggabungkan penelitian kualitatif dan kuantitatif.Data keterampilan menulis makalah diperoleh melalui hasil tugas proyek menulis makalah dan hasil observasi kegiatan di kelas. Selain itu, data diperoleh juga melalui penyebaran angket kepada mahasiswa. Analisis data kualitatif dengan beracuan pada teori Jacob dalam bukunya Sihabudin. Adapun analisis data kuantitatif menggunakan uji t. Berdasarkan hasil analisis data terdapat kenaikan yang berarti dari setiap perlakuan. Sebelum model pendekatan sistem diterapkan, nilai rata-rata mahasiswa sebesar 2,153 dan pada penerapan model ujicoba 1 nilai rata-rata mahasiswa menjadi 2,800 atau megalami kenaikan $23 \%$. Pada penerapan model pendekatan sistem ujicoba2 nilai mahasiswa meningkat menjadi 3,18 atau $32 \%$. Berikutnya pada penerapan model pendekatan sistem ujicoba3 nilai mahasiswa menjadisebesar 3,34 atau meningkat $36 \%$. Setelah seluruh model diterapkan maka nilai mahasiswa menjadi 3,60 atau atau meningkat $40 \%$, sehingga memenuhi nilai yang diharapkan (ideal).
\end{abstract}

Kata Kunci: Keterampilan Menulis, Pendekatan Sistem

\begin{abstract}
Scientific papers are written about science compiled systematically using proper grammar and correct. One type of scientific work is paper. One approach that can be applied in writing papers is a systems approach. the first step of a systems approach is the planning, implementation, observation to recognize the controversy, reflection and then weigh to solve the problem, and determine the proper evaluation of the problems. The purpose of this study is to determine the effect the development of writing skills evaluation papers with a systems approach. This study uses research and development / research and developments $(R \& D)$ is the research that combines qualitative and quantitative research. Data writing papers skills obtained through project tasks writing papers and the observation of classroom activities. In addition, the data obtained also through a questionnaire to students. Beracuan qualitative data analysis with the theory of Jacob in his Sihabudin. The analysis of quantitative data using the $t$ test. Based on the results of data analysis there is a substantial increase of each treatment. Before the model of a systems approach is applied, the average value of 2,153 students and the application of the first test model of the average value of 2,800 or megalami student into a $23 \%$ rise. On the application of the model test systems approach 2 grades of students increased to 3.18 or $32 \%$. Next on the application of the model systems approach ujicoba3 student value amounted to 3.34 , an increase of $36 \%$. After the entire model is applied, the value of the student to 3.60 or an increase of $40 \%$, thus meeting the expected value (ideal).
\end{abstract}

Key Words: Writing Skills, Systems Approach 


\section{A. PENDAHULUAN}

Keterampilan menulis memiliki peranan penting dalam kehidupan. Hampir semua kegiatan tidak terlepas dari kegiatan menulis. Perkembangan ilmu pengetahuan dan teknologi dapat ditemukan dari hasil karya penulisan, baik dalam bidang pendidikan, ilmu pengetahuan, teknologi, analisis sastra, dan lain sebagainya.Karyatulis ilmiah merupakan tulisan yang membahas ilmu pengetahuan disusun secara sistematis dengan menggunakan bahasa yang baik dan benar. Karya ilmiah merupakan bagian yang tidak terpisahkan di lingkungan akademik karena karya ilmiah menjadi tugas utama dan menjadi syarat dalam setiap mata kuliah dan kelulusan. Karya ilmiah menjadi tolok ukurinsan akademik dalam penerapan wawasan keilmuan yang dimilikinya.

Makalah merupakan salah satu karya ilmiah yang membahas ilmu pengetahuan berdasarkan kajian teoritis dan kajian lapangan. Dalam menulis makalah diperlukan keterampilan menulis dan menerapkannya dalam tahapan awal penulisan. Sebelum kita menulis makalah sebagai langkah awal kita menentukan tema dan pembatasan tema, langkah berikutnya adalah menentukan tujuan dan mengumpulkan referensi yang berkaitan dengan judul. Setelah itu kita membuat kerangka karangan.

Pendekatan sistem merupakan proses pemecahan masalah secara sistematis bermulai dari John Dewey, seorang profesor filosofi dari Colombia University. Ia mengidenfikasikan tiga seri penelitian yang terlibat dalam memecahkan suatu kontroversi secara memadai. Peneliti merasa penting memilih pendekatan sistem dalam pengembangan evaluasi keterampilan menulis makalah karena dengan pendekatan sistem peneliti dapat mengetahui permasalahan di lapangan yang merupakan hambatan dalam keterampilan menulis. Adapun langkah awal dari pendekatan sistem adalah perencanaan, pelaksanaan, observasi untuk mengenali kontroversi, refleksi lalu menimbang untuk memecahkan masalah, dan menentukan evaluasi yang tepat dengan permasalahan.

\section{B. KAJIAN TEORI DAN METODE}

\section{Kajian Teori}

\section{a. Ihwal Menulis}

Dalam menulis semua unsur keterampilan berbahasa harus dikonsentrasikan secara penuh agar mendapatkan hasil yang benar-benar baik. Tarigan (1986: 15) menyatakan bahwa menulis dapat diartikan sebagai kegiatan menuangkan ide/gagasan dengan bahasa tulis sebagai media penyampai. Semi (2007:14) dalam bukunya mengungkapkan pengertian menulis adalah suatu proses kreatif memindahkan gagasan kedalam lambang-lambang tulisan. Dari pengertian tersebut dapat dikatakan bahwa menulis itu merupakan sebuah proses yang berkelanjutan dimana gagasan yang ada dalam pikiran kita itu harus disusun kedalam bentuk tulisan yang berupa lambanglambag dan menghasilkan sebuah karya tulis yang bermakna dan mengandung arti.

Menulis dapat didefinisikan sebagai penggunaan simbol-simbol grafis (huruf atau rangkaian huruf yang berhubungan dengan suara yang kita buat yang umumnya terjadi bila kita berbicara), yang dibagi menurut konvensi tertentu untuk membentuk kata-kata. Kata-kata tersebut selanjutnya disusun dalam kalimat.

\section{b. Tujuan Menulis}

Menurut Semi (2007:14), "Setiap orang yang akan menulis tentu mempunyai niat atau maksud didalam hati atau pikiran apa yang hendak dicapainya dengan menulis. Niat atau maksud itulah yang dinamakan tujuan menulis.

Tujuan orang menulis adalah sebagai berikut:

1) Untuk menceritakan sesuatu

2) Untuk memberikan petunjuk atau pengarahan

3) Untuk menjelaskan sesuatu

4) Untuk Meyakinkan

5) Untuk merangkum

\section{c. Faktor-faktor yang memengaruhi keterampilan menulis}

Damono (1977) menyebutkan bahwa kebiasaan membaca, pengetahuan dasar tata bahasa, dan penggunaan kamus merupakan faktor yang memengaruhi kemampuan dan keterampilan menulis. Pelbagai informasi bisa diperoleh dari bacaan. Membaca merupakan kegiatan untuk memperoleh pelbagai informasi. Informasi yang bisa memperkaya wawasan. Membaca merupakan upaya agar bisa menulis karena dengan membaca akan memiliki gagasan-gagasan yang akan dituangkan dalam bentuk tulisan. Kosa kata, cara penyusunan kalimat dan alinea, penentuan gagasan, da gaya menulis bisa didapatkan melalui membaca. 
Pengetahuan tata bahasa jelas merupakan faktor yang tidak bisa diabaikan oleh seorang penulis. Dalam buku-buku komposisi, pengetahuan dasar ketatabahasaan itu dapat kita pelajari.Pada waktu membaca mungkin terdapat kata atau istilah yang kurang kita pahami, dari kata atau istilah yang kurang kita pahami itu kita dapat menggunakan kamus sebagai pedoman untuk menambah wawasan kita tentang kata dan istilah itu agar tidak salah tafsir. Kamus bahasa dan ensiklopedi merupakan sumbangan besar bagi penulis.

\section{d. Langkah-Langkah Menulis Makalah}

1) Tahap Persiapan

a) Pemilihan Tema

b) Pembatasan Tema

c) Menentukan maksud dan tujuan penulisan

d) Menyusun Outline

2) Tahap Pengumpulan Data

3) Penyusunan instrument

4) Uji coba instrument

5) Pengumpulan data

6) Melakukan wawancara dengan nara sumber yang layak

7) Penyebaran angket

8) Tahap Analisis Data

a) Kualitatif

(1) Identifikasi data

(2) Klasifikasi data

(3) Analisis data

(4) Interpretasi data

(5) Simpulan

b) Kuantitatif

9) Tahap penyusunan draft laporan

10) Menyajikan hasil studi pustaka.

11) hasil pengumpulan data

12) hasil analisis data

13) Simpula

14) Tahap Revisi

Tahapan menulis diatas harus dilaksanakan sebelum kita menulis karya ilmiah, agar tulisan kita sistematis dan terarah. Hal tersebut dapat membantu penulis jika terdapat kebakuan kata dalam penulisan karya ilmiah sehingga penulis tidak merasa kesulitan dalam penulisan. Dalam menulis karya ilmiah perlu perencanaan yang dapat menunjang keberlangsungan penelitian.

\section{e. Karya Tulis Ilmiah}

Karya ilmiah atau tulisan ilmiah adalah suatu karangan yang disusun secara sistematis dan bersifat ilmiah. Sistematis berarti bahwa karangan atau karya tulis tersebut disusun menurut aturan tertentu sehingga kaitan antara bagian-bagian tersebut sangat jelas dan padu. Bersifat ilmiah, berarti bahwa karya tulis tersebut menyajikan satu deskripsi, gagasan, argumentasi atau pemecahan masalah yang didasarkan pada berbagai bukti empirik atau kajian teoretis sehingga para pembacanya dapat merunut atau mencari kebenaran bukti empirik atau teori yang mendukung gagasan tersebut.

Menurut Brotowijoyo dalam Arifin (1993:2), karangan ilmiah adalah karangan ilmu pengetahuan yang menyajikan fakta dan ditulis menurut metodologi penulisan yang baik dan benar. Karangan ilmiah harus ditulis secara jujur dan akurat berdasarkan kebenaran tanpa mengingat akibatnya. Kebenaran dalam karya ilmiah bukan merupakan kebenaran normatif, melainkan kebenaran objektif dan positif sesuai dengan fakta dan data di lapangan.

Berdasarkan pengertian di atas, sebuah karya ilmiah dapat dikenali dari ciri-ciri seperti yang disebutkan sebagai berikut.

1) Dari segi isi, karya ilmiah menyajikan pengetahuan yang dapat berupa gagasan, deskripsi tentang sesuatu atau pemecahan suatu masalah.

2) Pengetahuan yang disajikan didasarkan pada fakta atau data (kajian empirik) atau pada teori-teori yang telah diakui kebenarannya.

3) Sebuah karya ilmiah mengandung kebenaran yang objektif serta kejujuran dalam penulisan.

4) Bahasa yang digunakan adalah bahasa baku dan banyak menggunakan istilah teknis, di samping istilah-istilah yang bersifat denotatif.

5) Sistematika penulisan mengikuti cara tertentu.

\section{f. Makalah}

Makalah merupakan salah satu karya ilmiah yang membahas suatu kajian ilmu berdasarkan teoritis dan kajian lapangan disertai interpretasi penulis terhadap teori. Suatu makalah dikategorikan baik jika makalah tersebut dapat memberikan manfaat dan dapat menyelesaikan permasalahan. Syarat makalah yang baik salah satunya cermat, tepat waktu, sederhana dan jelas. Seluruh insan akademik harus terampil dalam menulis makalah. Seperti yang dikemukakan oleh Abidin (2010 hlm.39) Makalah adalah salah satu jenis karya tulis ilmiah yang membahas satu permasalahan tertentu sebagai hasil kajian pustaka ataupun kajian lapangan. Makalah disusun dengan tujuan untuk 
memenuhi tugas tertentu (tugas akademik maupun tugas nonakademik). Sebagai sarana untuk mendemonstrasikan pemahaman penulis tentang pokok permasalahan teoretis yang dikaji atau kemampuan penulis dalam menerapkan suatu prosedur, prinsip, atau teori yang berhubungan dengan masalah tertentu.Sebagai sarana untuk menunjukkan kemampuan pemahaman terhadap isi dari berbagai sumber yang digunakan untuk memecahkan suatu masalah, jadi bukan rangkuman.

\section{g. Ciri-Ciri Makalah}

Adapun ciri khusus makalah yang baik harus:

a. Data yang digunakan mempunyai validitas yang tinggi dan analisis serta interpretasi haruslah objektif.

b. Makalah harus mampu menunjukkan kejujuran ilmiah penulis. Dalam hal ini, penulis makalah harus menyebutkan dengan jelas sumber data dan pendapat yang digunakan dalam makalahnya.

c. Makalah harus menggunakan bahasa yang jelas, tegas, singkat, sederhana, dan teliti.

d. Makalah harus sistematis dan utuh.

Fungsi penulisan makalah adalah untuk melatih mahasiswa agar terampil dalam menulis karya ilmiah dan melatih mahasiswa agar terampil dalam berinterpretasi terhadap teori, sehingga mahasiswa dapat memahami ilmu berdasarkan pemahaman bacaan.

\section{h. Sistematika Makalah}

Makalah harus memiliki sistematika yang benar. Menurut Abidin (2010 hlm.41) sistematika makalah dibedakan berdasarkan jenis makalah. Sistematika makalah lengkap adalah sebagai berikut.

Bagian Awal, terdiri atas:

Halaman Judul

Kata Pengantar

Daftar Isi

Daftar Gambar/Tabel/ Lampiran/ Lambang atau Singkatan (jika diperlukan)

Bagian Isi, terdiri atas:

BAB 1 PENDAHULUAN

1.1 Latar Belakang

1.2 Batasan Masalah

1.3 Masalah

1.4 Tujuan
1.5 Manfaat Makalah

1.6 Metode Penyusunan

BAB 2 PEMBAHASAN

2.1 Tinjauan/Kajian Teoretis

2.2 Pembahasan

BAB 3PENUTUP

3.1 Simpulan

3.2 Saran

Bagian Penutup, terdiri atas

Daftar Pustaka

Lampiran (jika ada)

Sistematika yang diuraikan di atas merupakan satu kesatuan yang utuh dan tidak dapat dipisahkan dan bolak-balik susunannya.

\section{i. Pendekatan Sistem}

Proses pemecahan masalah secara sistematis bermulai dari John Dewey, seorang profesor filosofi dari Colombia University. Dewey mengidenfikasikan tiga seri penelitian yang terlibat dalam memecahkan suatu kontroversi secara memadai.

1) Mengenali kontroversi

2) Menimbang klaim alternatif

3) Membentuk penilaian

Tahap-tahap dan langkah-langkah pendekatan sistem

Tahap I: Usaha Persiapan

Langkah 1: Memandang sekolah sebagai suatu sistem.

Langkah 2: Mengenali sistem lingkungan.

Langkah 3: Mengindentifkisi subsistem sekolah.

Tahap II: Usaha Definisi

Langkah4: Bergerak dari tingkat sistem ke subsistem.

Langkah 5: Menganalisa bagian sistem-sistem dalam urutan tertentu

Tahap III: Usaha Solusi

Langkah 6: Mengidentifikasi solusi alternatif

Langkah 7: Mengevaluasi solusi alternatif

Langkah 8: Memilih solusi terbaik

Langkah 9: Menerapkan solusi terbaik

Langkah 10: Membuat tindak lanjut bahwa solusi itu efektif

Istilah sistem menurut KBBI adalah perangkat unsur yang secara teratur saling berkaitan sehingga membentuk suatu totalitas. Dengan demikian 
dalam sistem diperlukan seperangkat komponen yang saling berkaitan dengan yang lainnya dalam mencapai suatu maksud atau tujuan. Tujuan suatu sistem menurut Hamalik dapat bersifat alami dan bersifat manusiawi. Tujuan yang alami tak mungkin menjadi tujuan-tujuan yang tinggi tingkatannya, bahkan mungkin bernilai sangat rendah. Tujuan sistem yang bersifat manusiawi (man-made) senantiasa dapat berubah. Tujuantujuan itu dimaksudkan untuk memenuhi tuntutan lingkungan yang senantiasa berubah, akibat perubahan lingkungan atau karena tujuan itu bersifat perorangan (personal). Jadi perubahan sistem terjadi karena terdapat perubahanperubahan di lingkungan.

Pada akhir tahun 1950 dan awal 1960-an, pendekatan sistem mulai dipergunakan dalam bidang latihan dan pendidikan (merumuskan masalah), analisis kubutuhan dengan maksud mentransformasikannya menjadi tujuan-tujuan (analisis masalah), desain metode dan materi instruksional (pengembangan suatu pemecahan), pelaksanaan secara eksperimental, dan akhirnya menilai dan merevisi. Adapun desain sistem pengajaran menurut Hamalik adalah sebagai berikut.

\section{Metode}

Penelitian ini menggunakan metode penelitian dan pengembangan/research and developments (R\&D). Penelitian $R \& D$ digunakan untuk menghasilkan produk pengembangan evaluasi keterampilan menulis makalah dengan pendekatan sistem, dan menguji keefektifan alat evaluasi tersebut. Menurut Sugiyono (2011, hlm.297) untuk dapat menghasilkan produk tertentu digunakan penelitian yang bersifat analisis kebutuhan dan untuk menguji keefektifan produk tersebut supaya dapat berfungsi di masyarakat luas, maka diperlukan penelitian untuk menguji keefektifan produk tersebut.

Adapun alur penelitian $R \& D$ tersebut secara rinci diawali dengan kegiatan studi pustaka lalu diteruskan dengan studi lapangan untuk melihat pola pembelajaran yang diterapkan selama ini oleh dosen. Setelah melakukan analisis temukan, berikutnya peneliti mendesain model pembelajaran yang akan dicobakan. Desain model diujicobakan ke sampel terbatas yang ditetapkan, lalu dievaluasi dan diperbaiki bila masih terdapat kelemahan. Hasil evaluasi dan perbaikan tersebut dijadikan sebagai model hipotetik. Model hopotetik berikutnya diterapkan dalam pembelajaran di kelas sebagai pemberlakuan tahap pertama lalu dievaluasi den disempurnakan bila dipandanng masih terdapat kekurangan atau kelemahan yang masih terdapat kekurangan atau kelemahan yang masih muncul, berikutnya diterapkan kembali dalam pembelajaran di kelas sebagai pemberlakuan tahap kedua, lalu dievaluasi dan disempurnakan kembali bila masih terdapat kelemahan. Demikian seterusnya sampai penelitian tersebut mendapatkan hasil yang diharapakan.

Data penelitian ini akan dikumpulkan melalui penulisan makalah dan observasi kegiatan mahasiswa di kelas selama proses pembelajaran berlangsung. Data tentang tanggapan mahasiswa diambil dari penyebaran angket kepada mahasiswa. Penyebaran angket dilakukan diawal pembelajaran, hal ini dilakukan agar menemukan permasalahan tetntang tahapan menulis, tata tulis karya ilmiah dan penilaian makalah dari dosen, yang peneliti jadikan rancangan model pengembangan evaluasi keterampilan menulis makalah dengan pendekatan sistem.

Pengujian Perbedaan Antara Pretest dan Postest pada Ujicob1, Ujicoba2 Dan Ujicoba3, menggunakan uji paired sample $t$ tes, pada prinsipnya ingin menguji suatu nilai tertentu apakah berbeda secara nyata (signifikan) atau tidak sebelum dan sesudah perlakuan. Pengambilan keputusan pada uji t dua sampel berkaitan adalah dengan cara :

a. Membandingkan $t$ hitung dengan $t$ table. Jika statistic hitung > statistic table maka $\mathrm{H}_{\mathrm{o}}$ ditolak dan $\mathrm{H}_{\mathrm{a}}$ diterima. Jika statistic hitung < statistic table maka $\mathrm{H}_{0}$ diterima dan $\mathrm{H}_{\mathrm{a}}$ ditolak

b. Berdasarkan nilai probabilitas. Jika probabilitas $>0,05$, maka $\mathrm{H}_{\mathrm{o}}$ diterima dan $\mathrm{H}_{\mathrm{a}}$ ditolak. Jika probabilitas $<0,05$ maka $\mathrm{H}_{\mathrm{o}}$ ditolak dan $\mathrm{H}_{\mathrm{a}}$ diterima. (Singgih Santoso, $2002: 231-235$ ).

Untuk memperoleh informasi tentang pengaruh pengembangan evaluasi keterampilan menulis makalah dengan pendekatan sistem., dilakukan pengujian statistik paired sample $t$-test.

\section{HASIL DAN PEMBAHASAN}

\section{Hasil}

\section{a. Pengembangan Evaluasi Keterampilan Menulis Makalah Dengan Pendekatan Sistem}


Berdasarkan pada teori Hamalik penulis merancang pengembangan evaluasi keterampilan menulis makalah dengan pendekatan sistem sebagai berikut.

1) Merumuskan tujuan sebagai berikut.

a) Untuk mengetahui kendala mahasiswa dalam langkah-langkah menulis.

b) Untuk mengetahui kendala mahasiswa dalam menulis makalah.

c) Untuk mengetahui evalusi keterampilan menulis.

d) Dari temuan masalah dihasilkan alat evaluasi keterampilan menulis makalah dengan pendekatan sistem yang merupakan pengembangan program.

2) Langkah awal dilakukan pre test menulis makalah dengan tema "Analisis Kesalahan Berbahasa" dan post test dengan tema yang sama.

3) Peneliti menentukan rangkaian materi Kegiatan Belajar dan Belajar (KBB) sebagai berikut.

a) Teori menulis dan langkah-langkah dalam menulis.

b) Karya tulis ilmiah dan Makalah

c) Tata Tulis Karya Ilmiah (TTKI)

d) Analisis Kesalahan Berbahasa

4) Diskusi materi dan praktik dalam penulisan makalah.

5) Melaksananakan kegiatan belajar dan belajar (KBB) dengan pendekatan sistem.

6) Pedoman perbaikan atau revisi, yang merupakan pengembangan alat evaluasi setelah dilaksanakan perbaikan.

\section{b. Langkah pembelajaran dengan pendekatan Sistem}

1) Dosen mengenali permasalahan dalam menulis makalah dari hasil penilaian angket.

2) Dosen merancang pembelajaran dari permasalahan yang dikenali.

3) Dosen menerapkan metode pembelajaran yang telah dirancang.

4) Dosen melakukan evalusi dari uji coba I

5) Dosen melakukan perbaikan dari kekurangan uji coba I

6) Dosen melakukan evaluasi dari uji coba II

7) Dosen melakukan perbaikan dari uji coba II

8) Dosen melakukan evaluasi uji coba III.

9) Hasil dari ketiga uji coba yang dilakukan dianalisis dan dilakukan pengolahan data sesuai dengan tahapan metode $\mathrm{R} \& \mathrm{D}$
10) Dosen menemukan pengembangan alat evaluasi dari keterampilan menulis makalah dengan pendekatan sistem

Berdasarkan pada temuan di lapangan peneliti menemukan pelbagai permasalahan dalam menulis karya ilmiah, diantaranya sebagai berikut.

1) Mahasiswa mengetahui langkah-langkah menulis makalah, tapi dalam praktiknya kurang memahami dengan alasan hanya materi saja yang diterima mahasiswa kemudian diberi tugas dan tidak ada tindak lanjut dari tugas tersebut. Dari permasalahan ini peneliti memutuskan untuk menggunakan evaluasi dalam tahap pra penulisan agar mahasiswa termotivasi untuk melakukan kegiatan pra penulisan dan dilakukan perbaikan melalui diskusi antara dosen, mahasiswa dan kelompok diskusi.

2) Mahasiswa mengetahui karya ilmiah namun dalam praktik penulisan karya ilmiah kurang terampil. Dari permaslahan tersebut peneliti merasa penting untuk memberikan penilaian draf makalah sebagai tahap pengembangan kerangka karangan yang telah dibuat dalam tahap pra penulisan, sebagai upaya untuk memotivasi mahasiswa dalam pengembangan keterampilan menulis.

3) Mahasiswa mengeluhkan tentang penulisan makalah, terkait dengan penilaian yang tidak jelas. Pekerjaan yang tidak mudah, namun para mahasiswa jarang mendapat revisi dari hasil tulisannya, sehingga para mahasiswa tidak mengetahui letak kesalahannya. Dan permasalahan ini yang menjadikan mahasiswa terampil untuk copy paste sebagai jalan pintas. Jika permasalahan ini berkelanjutan berakibat kemunduran khusunya di bidang pendidikan. Peneliti merasa penting untuk mengembangkan evaluasi keterampilan makalah dengan pendekatan sistem. Penilaian tersebut merupakan serangkaian kegiatan yang berkelanjutan, adapun kriteria penialian makalah sebagai berikut. 


\begin{tabular}{|c|c|c|c|c|}
\hline NO & ASPEK & KATEGORI & SKOR & KETERANGAN \\
\hline 1 & $\begin{array}{l}\text { Tema, judul } \\
\text { dan penentuan } \\
\text { maksud/tujuan. }\end{array}$ & $\begin{array}{l}\mathrm{A}=\text { jika tema, orsinilitas judul } \\
\text { dan tujuan sangat relevan. } \\
\mathrm{B}=\text { jika tema dan judul cukup } \\
\text { orsinil dan relevan dengan } \\
\text { tujuan. } \\
\mathrm{C}=\text { jika tema dan judul } \\
\text { kurang orsinil dan relevan } \\
\text { dengan tujuan } \\
\mathrm{D}=\text { jika tema dan judul tidak } \\
\text { orsinil dan relevan dengan } \\
\text { tujuan }\end{array}$ & $\begin{array}{lll}7 \% \text { dengan rincian } & \text { sebagai } \\
\text { berikut. } & & \\
A=6-7 & & \\
B=4,1-5,9 & & \\
C=2,1-4 & & \\
D=1-2 & & \end{array}$ & $\begin{array}{l}\text { Penskoran tersebut } \\
\text { terlihat dari penulisan di } \\
\text { kertas buram atau kertas } \\
\text { HVS }\end{array}$ \\
\hline 2 & $\begin{array}{l}\text { Kerangka } \\
\text { Karangan }\end{array}$ & $\begin{array}{l}A=\text { susunan runut } \\
B=\text { susunan cukup runut } \\
C=\text { susunan kurang runut } \\
D=\text { susunan tidak runut }\end{array}$ & $\begin{array}{l}\text { Skor } 8 \% \text { dengan rincian sebagai } \\
\text { berikut. } \\
A=6,1-8 \\
B=4,1-6 \\
C=2,1-4 \\
D=1-2\end{array}$ & $\begin{array}{l}\text { Penskoran tersebut } \\
\text { terlihat dari penulisan di } \\
\text { kertas buram atau kertas } \\
\text { HVS }\end{array}$ \\
\hline
\end{tabular}

\section{c. Tahap Pra Penulisan (pre-writing)}

1) Pemilihan Tema

2) Pembatasan Tema

3) Menentukan maksud dan tujuan penulisan

4) Menyusun Outline

Pada tahap pra penulisan para mahasiswa melakukan penulisan di kertas buram atau dalam kertas HVS yang dibagikan oleh dosen, tema yang dipilih harus kajian yang digemari oleh mahasiswa, hal dilakukan agar mempermudah mahasiswa ketika berkendala dalam tulisannya. Setelah itu mahasiswa menginventarisasi topik-topik bawahan dan penentuan judul karya ilmiah. setelah judul penentuan maksud dan tujuan yang harus relevan dengan judul. Kegiatan terakhir dari pra penulisan adalah membuat kerangka karangan. Adapun skor dalam kegiatan pra penulisan adalah $15 \%$ dengan rincian skor sebagai berikut.

\begin{tabular}{llll}
\hline ASPEK & KATEGORI & SKOR & KETERANGAN \\
\hline Sistematika & A= Draf & Skor & Penskoran \\
Makalah & makalah & $15 \%$ & tersebut terlihat \\
& sistematis & dengan & dari penulisan di \\
& B= Draf & rincian & kertas buram atau \\
& makalah cukup & sebagai & kertas HVS \\
& sistematis & berikut. & \\
C= Draf & A=10- & \\
& makalah & $6-15$ & \\
kurang & B=7,1- & \\
& sistematis & 10,5 & \\
& D= Draf & C=4,1-7 & \\
& makalah tidak & $\mathrm{D}=1-4$ & \\
& sistematis & & \\
& & & \\
& & &
\end{tabular}

\section{d. Tahap Penulisan (writing)}

Dalam tahap penulisan adalah membuat draf makalah dan pengembangan dari draf tersebut. Dari draf yang ditulis oleh mahasiswa dalam kertas buram atau HVS dosen memberi masukan dan kritikan mengenai bagaian-bagian yang harus ditambah dan bagian-bagian yang harus dihilangkan. Setelah revisi draf makalah kemudian mahasiswa melakuan kegiatan penulisan. Skor penilaian draf makalah adalah $15 \%$.

Penulisan draf makalah harus sistematis, item-item yang harus ada dalam draf makalah adalah sebagai berikut.

Bagian Awal, terdiri atas:

Halaman Judul

Kata Pengantar

Daftar Isi

Daftar Gambar/Tabel/ Lampiran/ Lambang atau Singkatan (jika diperlukan)

Bagian Isi, terdiri atas:

BAB 1 PENDAHULUAN

1.1 Latar Belakang

1.2 Batasan Masalah

1.3 Masalah

1.4 Tujuan

1.5 Manfaat Makalah

1.6 Prosedur Makalah

BAB 2 PEMBAHASAN

2.1 Tinjauan/Kajian Teoretis (Teori yang relevan dengan judul)

2.2 Pembahasan (pembahasan masalah berdasarkan teori) 
BAB 3 PENUTUP

3.1 Simpulan (berbentuk pointer relevan dengan rumusan masalah)

\subsection{Saran}

Bagian Penutup, terdiri atas:

Daftar Pustaka (sejumlah pustaka yang digunakan di Bab 2).

Lampiran (jika ada)

\section{e. Tahap Hasil Penulisan (post-writing)}

Dalam tahap post writing, penilaian pada hasil penulisan atau makalah jadi. Adapun aspek penilaian terdiri dari beberapa butir, adalah sebagai berikut.

Penggunaan Bahasa

a. Ejaan

b. Pilihan kata

c. Struktur kalimat

d. Paragraf

e. Gaya bahasa

Isi dan Penalaran

a. Keruntutan

b. Pengembangan isi

c. Relevansi argumentasi

d. Kedalaman argumentasi

Penutup

a. Simpulan relevansi dari rumusan masalah

b. Saran baik praktis maupun teoritis

\section{Pembahasan}

a. Perbedaan Pretest dengan Postest

Adapun pengujian hipotesisnya menggunakan twotiled ( 2 arah) dengan hipotesis :

Ho : $\mu_{1}=\mu_{2}$

Ha: $\mu_{1} \neq \mu_{2}$

Ho : Tidak terdapat perbedaan nilai tes peserta didik antara sebelum dan sesudah pelaksanaan pembelajaran keterampilan menulis makalah dengan pendekatan sistem setelah seluruh ujicoba dilakukan

$\mathrm{Ha}$ : Terdapat perbedaan nilai tes peserta didik antara sebelum dan sesudah pelaksanaan pembelajaran keterampilan menulis makalah dengan pendekatan sistem setelah seluruh ujicoba dilakukan

Kriteria pengambilan keputusan menggunakan $\alpha=$ $5 \%$. Jika $\mathrm{t}$ hitung $>\mathrm{t}$ tabel atau nilai probabilitas (sig) $\leq 0,05$ maka Ho ditolak. Jika t hitung $>\mathrm{t}$ tabel nilai probabilitas $(\mathrm{sig}) \geq 0,05$ maka Ho diterima. Hasil perhitungan disajikan dalam tabel sebagai berikut:

Berdasarkan pengujian statistik uji $\mathrm{t}$ (paired sample $t$-test), tercatat nilai rata-rata Pretest (tanpa perlakuan dalam keterampilan menulis makalah) diterapkan adalah 2,15 dengan jumlah mahasiswa 38orang, sementara nilai rata-rata tes mahasiswa setelah semua model diterapkan (postest)dalam pendekatan sistem dalam keterampilan menulis makalah diterapkan adalah 3,60. Berarti ada peningkatan nilai rata-rata hasil belajar peserta didik setelah pendekatan sistem diterapkan.

Berdasarkan perhitungan, diperoleh nilai probabilitas (sig) pada $\mathrm{df}=37$ adalah $0,000<0,05$ dan $\mathrm{t}$ hitung $=62,325>\mathrm{t}$ tabel $=2,026$ pada $\alpha=$ $5 \%$. Dengan demikian berarti ada perbedaan yang sangat berarti (sangat signifikan) nilai tes peserta didik antara sebelum dan sesudah pelaksanaan model pendekatan sistem dalam keterampilan menulis makalah. Dengan demikian terdapat pengaruh yang berarti pendekatan sistem yang digunakan dalam keterampilan menulis makalah.

Secara keseluruhan penerapan model pendekatan sistem dalam keterampilan menulis makalah adalah sebagai berikut:

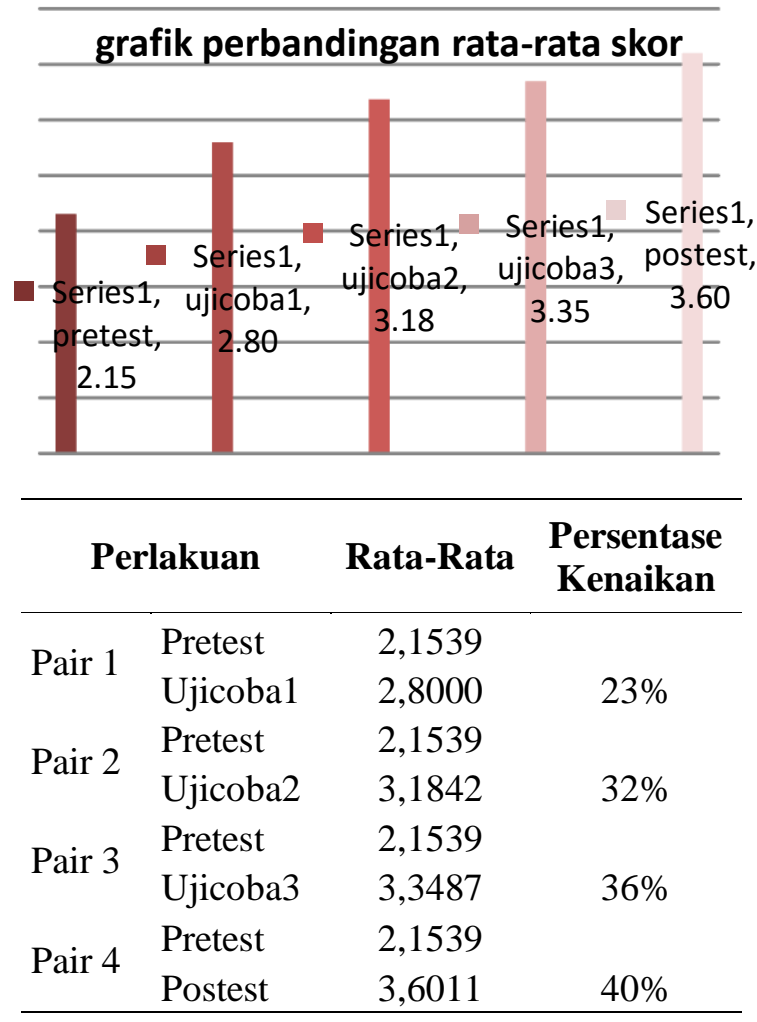


Berdasarkan tabel maka terdapat kenaikan yang berarti dari setiap perlakuan. Sebelum model pendekatan sistem diterapkan, nilai rata-rata mahasiswa sebesar 2,153 dan pada penerapan model ujicoba1 nilai rata-rata mahasiswa menjadi 2,800 atau megalami kenaikan 23\%. Pada penerapan model pendekatan sistem ujicoba2 nilai mahasiswa meningkat menjadi 3,18 atau $32 \%$. Berikutnya pada penerapan model pendekatan sistem ujicoba3 nilai mahasiswa menjadisebesar 3,34 atau meningkat $36 \%$. Setelah seluruh model diterapkan maka nilai mahasiswa menjadi 3,60 atau atau meningkat $40 \%$, sehingga memenuhi nilai yang diharapkan (ideal)

\section{KESIMPULAN}

Keterampilan menulis yang menjadi pedoman peneliti adalah menggunakan kriteria penilaian dari Jacob (Shihabudin). Aspek yang dinilai dari keterampilan menulis adalah penggunaan bahasa yang meliputi: ejaan, pilihan kata, struktur kalimat, paragraf, gaya bahasa. isi dan penalaran meliputi: keruntutan; pengembangan isi; relevansi argumentasi; kedalaman argumentasi.

\section{Langkah Pembelajaran Pendekatan Sistem}

a. Dosen mengenali permasalahan dalam menulis makalah dengan menyebarkan angket.

b. Dosen merancang pembelajaran dari permasalahan yang dikenali.

c. Dosen menerapkan metode pembelajaran yang telah dirancang.

d. Dosen melakukan evalusi dari uji coba I

e. Dosen melakukan perbaikan dari kekurangan uji coba I

f. Dosen melakukan evaluasi dari uji coba II

g. Dosen melakukan perbaikan dari uji coba II

h. Dosen melakukan evaluasi uji coba III

i. Hasil dari ketiga uji coba yang dilakukan dianalisis dan dilakukan pengolahan data sesuai dengan tahapan metode $R \& D$

j. Dosen menemukan pengembangan alat evaluasi dari keterampilan menulis makalah dengan pendekatan sistem

2. Pengembangan evaluaasi menulis makalah dengan pendekatan sistem

a. Tahap Pra Penulisan (pre-writing)

1) Pemilihan Tema

2) Pembatasan Tema

3) Menentukan maksud dan tujuan penulisan

4) Menyusun Outline
Pada tahap pra penulisan para mahasiswa melakukan penulisan di kertas buram atau dalam kertas HVS yang dibagikan oleh dosen, tema yang dipilih harus kajian yang digemari oleh mahasiswa, hal dilakukan agar mempermudah mahasiswa ketika berkendala dalam tulisannya. Setelah itu mahasiswa menginventarisasi topik-topik bawahan dan penentuan judul karya ilmiah. setelah judul penentuan maksud dan tujuan yang harus relevan dengan judul. Kegiatan terakhir dari pra penulisan adalah membuat kerangka karangan.

\section{b. Tahap Penulisan (writing)}

Dalam tahap penulisan adalah membuat draf makalah dan pengembangan dari draf tersebut. Dari draf yang ditulis oleh mahasiswa dalam kertas buram atau HVS dosen memberi masukan dan kritikan mengenai bagaian-bagian yang harus ditambah dan bagian-bagian yang harus dihilangkan. Setelah revisi draf makalah kemudian mahasiswa melakuan kegiatan penulisan.

\section{c. Tahap Hasil Penulisan (post writing)}

Dalam tahap post writing, penilaian pada hasil penulisan atau makalah jadi. Adapun aspek penilaian terdiri dari beberapa butir, adalah sebagai berikut.

1) Penggunaan Bahasa

2) Ejaan

3) Pilihan kata

4) Struktur kalimat

5) Paragraf

6) Gaya bahasa

7) Isi dan Penalaran

8) Keruntutan

a) Pengembangan isi

b) Relevansi argumentasi

c) Kedalaman argumentasi

9) Penutup

a) Simpulan relevansi dari rumusan masalah

b) Saran baik praktis maupun teoritis

Penelitian ini merupakan langkah awal dari pengembangan $\mathrm{R} \& / \mathrm{D}$ tentang pengembangan evaluasi keterampilan menulis makalah dengan pendekatan sistem sehingga hasil penelitian ini dapat digunakan sebagai acuan dalam evaluasi keterampilan menulis makalah. Disarankan kepada peneliti untuk melakukan pengembangan keterampilan menulis berbasis keterampilan proses dengan pendekatan sistem 


\section{E. DAFTAR PUSTAKA}

Arifin, Z. (2002). Dasar-dasar Menulis Karya Ilmiah. Jakarta: Grasindo

Ary, D. dkk. (2007). Pengantar penelitian dalam pendidikan. Yogyakarta: Pustaka Pelajar.

Brown, H. D.(2008). Edisi kelima prinsip pembelajaran dan pengajaran bahasa.Jakarta: Kedutaan Besar Amerika Serikat.

Creswell, J.W. (2002). Research design: desain penelitian qualitative \&quantitative approaches. Pendekatan kualitatif. Alihbahasa angkatan III\&IV KIK-UI dan bekerjasama dengan Nur Khabibah. Jakarta: KIK Press.

Elfindri, dkk. (2010). Soft Skilluntuk pendidik.

(Tidak ada): Baduose Media.

Fathurrohman, P. \& Sobry S.(2007). Strategi belajar mengajar strategi mewujudkan pembelajaran bermakna melalui penanaman konsep umum \& konsep islami. Bandung: Refika Aditama.

Iskandarwassid \& Dadang S.(2008). Strategi Pembelajaran Bahasa. Bandung: Remaja Rosdakarya.

Joyce, Bruce dkk. (2009). Models of Teaching Model-Model Pengajaran Edisi Delapan:

Terjemahan Models of Teaching oleh Achmad Fawaid dan Ateilla Mirza. Yogyakarta: Pustaka Pelajar.

LPMP SMA Direktorat Pembinaan Sekolah Menengah Atas, Direktorat Jenderal Manajemen Pendidikan Dasar dan Menengah, Depdiknas.

Muslich, M.(2011). Pendidikan Karakter Menjawab Tantangan Krisis

Multidimentional. Jakarta: Bumi Aksara.

Nurgiyantoro, B.(2010). Penilaian Pembelajaran

Bahasa Berbasis Kompetensi. Yogyakarta: BPFE Yogyakarta.

Semi, M. A. (2007). Dasar-dasar keterampilan menulis. Bandung: Angkasa.

Sugiyono. (2010). Metode Penelitian Kuantitatif Kualitatif dan $R \& D$. Bandung. Alfabeta.

Sugiyono. (2011). Metode Penelitian Kombinasi (Mixed Methods). Bandung: Alfabeta.

Sukmadinata, N.S. (2008). Metode Penelitian Pendidikan. Bandung: Rosdakarya.

Tarigan, H.G. (1993). Strategi Pengajaran dan Pembelajaran Bahasa. Cetakan ke-1. Bandung: Angkasa.
Tarigan, H. G. (2000). Menulis sebagai Suatu Keterampilan Berbahasa.Cetakan ke-6. Bandung: Angkasa.

Tim Redaksi KBBI Pusat Bahasa. (2008). Kamus Besar Bahasa Indonesia Pusat Bahasa. Edisi Keempat. Jakarta: Gramedia Pustaka Utama. 